\title{
Aktivisme Politik Mahasiswa Islam Membangun Demokrasi Pasca Orde Baru
}

\section{Wahyu Hidayat*, Taufikurrahman \\ Universitas Sebelas Maret}

Jl. Ir. Sutami No.36, Kentingan, Kec. Jebres, Kota Surakarta, Jawa Tengah 57126

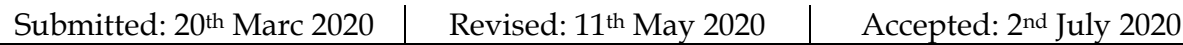

Abstract The practice of democracy in Indonesia has become a necessity, even having incarnated social reality in the life of nation and state. The social dynamics of politics that occurred in the 1998 reform era have brought a huge impact to the development of democracy. The study tried to assess the political activism of Islamic students in establishing new post-order democracy by taking a study of the intellectual role conducted by the Central Executive of Islamic Association of University Student (PB HMI) period 1997-1999. The study uses qualitative methods with historical approach, studied with the social construction theory of Peter L Berger. From this research it was found that in the process of construction of democracy understanding was conducted by HMI general Manager by conducting discussions, leadership training and Journal-making. This understanding is subject to the fundamental values of the HMI struggle (NDP) in accordance with the values of the "ke-Islaman" and "ke-Indonesiaan". Then internalized in the formulation of the political Bill. His influence on the dynamics of democracy in Indonesia is a supporter of the Pancasila ideology, establishing a prodemocracy political system and the development of the Civil Society. HMI as an Islamic-based religious organization is able to accept democracy as Islamic teachings. This research became the antithesis of the groups that rejected democracy. HMI accepts even encouraging democracy for the sake of national interests. Contribution of thought and leadership through its elits involvement in building democracy and the struggle for democratic enforcement in Indonesia.

Keywords: Democracy, Intelectual, HMI, Reform

Abstrak Praktik demokrasi di Indonesia telah menjadi suatu keharusan, bahkan telah menjelma realitas sosial dalam kehidupan berbangsa dan bernegara. Dinamika sosial politik yang terjadi di era reformasi 1998 telah membawa dampak besar bagi perkembangan demokrasi. Penelitian ini mencoba mengkaji aktivisme politik mahasiswa Islam dalam membangun demokrasi pasca orde baru dengan mengambil studi tentang peran intelektual yang dilakukan oleh Pengurus Besar HMI Periode 1997-1999. Penelitian ini menggunalan metode kualitatif dengan pendekatan historical research, dikaji dengan teori 
konstruksi sosial Peter L Berger. Dari penelitian ini ditemukan bahwa pada proses konstruksi pemahaman demokrasi dilakukan oleh Pengurus Besar HMI dengan melakukan diskusi, pelatihan kepemimpinan dan pembuatan jurnal. Pemahaman ini dilegitimasi yang disandarkan pada Nilai-Nilai Dasar Perjuangan HMI sesuai dengan nilai-nilai ke-Islaman dan ke-Indonesiaan. Kemudian diinternalisasikan dalam rumusan RUU Politik. Pengaruhnya terhadap dinamika demokrasi di Indonesia yakni sebagai pendukung ideologi Pancasila, membangun sistem politik yang prodemokrasi dan pembangunan Civil Society. HMI sebagai organisasi keagamaan yang berbasis Islam mampu menerima demokrasi sebagai ajaran Islam. Penelitian ini menjadi antitesis dari kelompokkelompok yang menolak demokrasi. HMI menerima bahkan mendorong demokrasi demi untuk kepentingan nasional. Kontribusi pemikiran dan kepemimpinan melalui keterlibatan elit-elitnya di dalam membangun demokrasi dan pergumulan penegakan demokrasi di Indonesia.

Kata Kunci: Demokrasi, Intelektual, HMI, Reformasi

\section{PENDAHULUAN}

Sejarah dinamika politik di Indonesia, mencatat berlangsungnya transisi kekuasaan dari negara otoriter yang didominasi militer ke sistem demokrasi sipil. Transisi kekuasaan tersebut menandai berakhirnya kekuasaan Soeharto sebagai Presiden RI pada 21 Mei 1998 yang memimpin Indonesia lebih dari 32 tahun. Mundurnya Soeharto adalah awal dari runtuhnya rezim Orde Baru menuju Era Reformasi. Transisi kekuasaan tersebut juga berdampak pada perubahan politik secara dramatis di Indonesia, semua menjadi saksi masuknya situasi yang disebut sebagai liberalisasi politik.

Proses transisi menuju reformasi demi mewujudkan sistem politik yang lebih demokratis sangat menyita perhatian publik Indonesia, baik dari kalangan intelektual dan masyarakat biasa. Salah satu kelompok intelektual yang paling giat menyuarakan demokrasi adalah kelompok mahasiswa yang memiliki tanggung jawab, yang tidak hanya lulus dari perguruan tinggi saja, tetapi melibatkan diri dalam persoalan politik, ekonomi, sosial dan kebudayaan, dan lingkungan masyarakatnya (Anwar, 1981: 28).

Peranan mahasiswa dalam sejarah politik di Indonesia sangat besar, seperti aksi demonstrasi dalam menurunkan Soeharto sebagai bagian dari perjuangan moral mahasiswa dalam keikutsertaannya 
memperjuangkan keadilan dan kemakmuraan masyarakat Indonesia. Gerakan mahasiswa seharusnya tidak berhenti sebagai gerakan moral dan gerakan menumbangkan rezim tirani, tetapi juga harus merebut dan membangun kekuasaan baru (Kusumah, 2004: 4).

Salah satu gerakan mahasiswa yang memiliki andil cukup besar, bahkan tidak bisa dipandang sebelah mata adalah Himpunan Mahasiswa Islam. Sebagai salah satu kelompok gerakan mahasiswa Islam, HMI telah melakukan gerakan sosialnya sebagai kontrol sosial dan moral. Organisasi ekstra-universitas terbesar di Indonesia dan memiliki massa potensial yang sewaktu-waktu dapat digerakkan melakukan pressure maupun dukungan politik (Mas'eod dan MacAndrews, ed, 1981: 56; Saleh, 1996: 4). Hal ini pernah dilakukan oleh HMI, sebagai organisasi yang mampu menggerakkan kadernya untuk menandingi organisasi revolusioner seperti yang dimiliki oleh PKI (Sulastomo, 2008: 160).

Sebagaimana diketahui, perjuangan tegaknya demokrasi bagi HMI tidak bisa dipisahkan dari dua komitmen yakni keislaman dan keindonesiaan (Sitompul, 2008:13). Kedua komitmen tersebut merupakan hasil dari pemikiran HMI yang tidak bisa dilepaskan dari realitas sosialkeagamaan yang ada di Indonesia. Seperti yang diungkapkan Lafran pane bahwa sikap akomodatif HMI tersebut merupakan kodrat bagi organisasi, karena menurutnya, HMI adalah nasionalis dahulu, baru kemudian Islam (Forum Pemuda, 1983). HMI tumbuh pada masyarakat pluralis dan mejemuk.

Sikap akomodatif ini paling menonjol ketika periode demokrasi terpimpin, HMI selalu berusaha menunjukkan diri berada sejalan dengan garis revolusioner rezim orde lama. Pada waktu itu, Sulastomo menjadi Ketua Umum Pengurus Besar (selanjutnya disingkat PB) HMI periode 1963-1966, bahkan sampai ketika Soekarno secara de facto tidak berkuasa lagi (Sulastomo, 1989: 46). HMI selalu mengambil sikap moderat, bahkan cenderung akomodatif, ketika berhadapan dengan kebijaksanaan pemerintah terutama yang tampak represif hingga sampai akhir tahun 1970-an.

Pada masa orde baru, HMI dihadapkan dengan situasi yang cukup berat yakni perdebatan mengenai rehabilitasi dari partai Masyumi, wacana pembaharuan pemikiran Islam oleh Nurcholis Majid, hingga kepada kebijakan pemerintah yang memaksa diberlakukannya azaz tunggal Pancasila yang kemudian berdampak pada perpecahan di internal HMI, antara pendukung azaz tunggal dan Islam. Bagi HMI yang tidak setuju dengan azaz tunggal mengadakan Kongres dengan mendirikan HMI MPO (Majelis Penyelamat Organisasi). 
Di era reformasi, HMI terlibat dalam demonstrasi yang turut membantu mempercepat peralihan kekuasaan. Habibie setelah disumpah sebagai Presiden oleh MPR, mengambil langkah cepat dengan mengangkat Syarwan Hamid sebagai Menteri Dalam Negeri yang baru untuk segera mengangkat dan memberi mandat kepada Tim tujuh untuk merevisi undang-undang politik. Tim tujuh ini diketuai oleh Ryaas Rasyid, dengan anggota Ramlan Surbakti, Andi Mallarangeng, Afan Gaffar, Djohermansyah Djohan, Luthfi Mutty dan Anas Urbaningrum (Ambardi, 2009:100). Keterlibatan Anas Urbaningrum dalam Tim Tujuh, yang pada waktu bersamaan masih menjabat Ketua Umum PB HMI merepresentasikan bentuk perjuangan HMI yang lebih praktis dalam memperjuangkan tegaknya demokrasi di Indonesia.

Setidaknya, terdapat beberapa pertimbangan menempatkan PB HMI periode 1997-1999, sebagai obyek kajian dalam penelitian ini. Diantaranya; Pertama, PB HMI Periode 1997-1999 bertepatan dengan menjelang pemilihan umum pertama pasca transisi kekuasaan. HMI memiliki tanggung jawab yang besar dalam mengawal cita-cita kehidupan bangsa Indonesia yang lebih demokratis. HMI pada saat itu terlibat dalam mengawal perjuangan reformasi pada Mei 1998 dan turut memberikan sumbangan pemikiran dalam menyusun RUU Politik.

Kedua, pada masa transisi kekuasaan pemerintah dari Orde Baru ke Era Reformasi, Ketua Umum PB HMI periode 1997-1999 dipimpin oleh Anas Urbaningrum. Sedangkan salah satu anggota dari Tim Tujuh yang ditugaskan untuk menyelesaikan RUU politik adalah Anas Urbaningrum. Sehingga, HMI secara organisatoris memiliki posisi yang strategis dan diuntungkan.

Ketiga, peralihan kekuasaan tentu cukup menguras tenaga dan fikiran. HMI sebagai organisasi gerakan mahasiswa dituntut mampu merespon peralihan zaman. Dengan sikap independensinya, HMI menjadi titik temu berbagai polarisasi kepentingan individu dan kelompok dimasa transisi kekuasaan. Sejak HMI mengikrarkan diri sebagai sumber nilai, motivasi dan inspirasi, maka Islam harus benarbenar menjadi nafas bagi segenap kehidupan berorganisasi dalam rangka mewujudkan fungsi HMI sebagai political force.

\section{METODE PENELITIAN}

Penelitian ini menggunakan jenis penelitian kualitatif dengan pendekatan sejarah (Historical Research). Menurut Borg dan Gall (dalam Djamal, 2015:103), penelitian sejarah adalah penyelidikan secara sistematis terhadap dokumen dan sumber-sumber lain yang mengandung fakta tentang pertanyaan-pertanyaan sejarawan di masa lampau. Penelitian ini 
dikaji dengan teori konstruksi sosial, Petel L Berger yang menekankan pada tindakan manusia sebagai realitas sosial dan aktor yang kreatif. Menurut Berger dan Luckmann (1990), realitas sosial adalah pengetahuan yang bersifat keseharian yang hidup dan berkembang di masyarakat, seperti konsep, kesadaran umum dan wacana publik sebagai hasil dari konstruksi sosial. Realitas sosial dikonstruksi melalui proses eksternalisasi, objektivikasi dan internalisasi.

\section{HASIL DAN PEMBAHASAN}

\section{Pergulatan HMI dalam Sejarah Keindonesiaan}

Latar belakang berdirinya HMI dipengaruhi oleh 3 (tiga) faktor. Pertama, situasi negara Republik Indonesia yang belum terlepas dari pengaruh penjajahan kolonial Belanda. Kedua, situasi umat Islam Indonesia saat itu belum bisa terlepaskan dari proses akulturasi yang terjadi ditengahtengah masyarakat pada masa lalu. Ketiga, situasi dunia perguruan tinggi dan kemahasiswaan sebelum kehadiran HMI pada tahun 1947 sangatlah dinamis. Julukan Yogyakarta sebagai kota pelajar sudah melekat sejak awal kemerdekaan, terutama sejak penghargaan pemerintah kepada Yogyakarta sebagai bekas ibukota Republik Indonesia.

Setelah mengalami berbagai pertumbuhan perguruan tinggi maupun perubahan situasi sosial budaya, politik dan pendidikan, berdirilah organisasi- organisasi mahasiswa daerah (lokal). Pada bulan Oktober 1946 berdiri Perserikatan Mahasiswa Yogyakarta (PMY), sebagai satusatunya organisasi mahasiswa di Yogyakarta, sementara di Solo berdiri Serikat Mahasiswa Indonesia (Sitompul, 2008: 69). Beberapa organisasi mahasiswa yang ada, tak satupun organisasi yang memiliki orientasi Islam, padahal perguruan tinggi dan dunia kemahasiswaan memiliki letak dan kedudukan yang sangat strategis. Apalagi sebelum HMI berdiri, sistem pendidikan di Indonesia dikuasai sistem pendidikan Barat, yang mengarah pada sekularisme yang berpotensi mendangkalkan agama dalam aspek setiap kehidupan, bahkan pendidikan barat diformulasikan sebagai faktor yang akan mengancurkan kekuatan Islam di Indonesia (Ibid, 2008: 70).

Melihat situasi kemahasiswaan dan perguruan tinggi yang demikian, sementara organisasi kemahasiswaan yang berbasis keislaman tidak tertampung aspirasinya, maka untuk mengisi kekosongan itu Lafran Pane memprakarsai mendirikan HMI pada tahun 1947. Sebagai organisasi pergerakan Islam kontemporer di Indonesia, HMI merupakan organisasi Islam yang mampu memainkan perannya mengambil basis anggota di perguruan tinggi. Peran HMI tersebut sebagai ajang pembentukan dan pembinaan mahasiswa kelas menengah masyarakat 
yang tinggal di kota. Mahasiswa-mahasiswa sebagai calon cendikiawan dan pemimpin di masa mendatang yang sehari-harinya berkumpul dengan ilmu pengetahuan dan teknologi sebagai penggerak modernisasi.

\section{Peran Intelektual PB HMI Periode 1997-1999}

Sejak berdirinya, karakteristik khas pola gerakan HMI adalah tidak memisahkan gerakan politik dengan gerakan keagamaan. Berpolitik bagi HMI adalah suatu keharusan, sebab untuk mewujudkan cita-cita dan tujuan HMI haruslah dilakukan secara politis. Bidang politik tidak akan mungkin dipisahkan dari HMI, sebab itu sudah merupakan watak asli HMI sejak lahir. Seperti yang tertuang dalam perumusan tujuannya, dalam perspektif interaksi terhadap sistem sosial politik pada awal berdirinya HMI yakni pertama, mempertahankan Negara Republik Indonesia dan mempertinggi derajat rakyat Indonesia; kedua, menegakkan dan mengembangkan ajaran agama Islam (Saleh, 1996:38).

Peran HMI pada tahun 1990-an kembali menguat. Hal ini bisa dilihat dari kongres ke 18 di Jakarta, yang memperlihatkan responsibilitas HMI mengenai berbagai kondisi kebangsaan dan kenegaraan di Indonesia. Salah satu respon HMI dalam bidang politik adalah penyikapan HMI terhadap fungsi DPR/ MPR yang dianggap mandul dan hanya menjadi stempel eksekutif. Menurut HMI, kekuatan yudikatif dan legislatif yang semestinya sejajar dengan eksekutif dalam sistem pemerintahan demokrasi, di Indonesia penerapannya malah timpang. Eksekutif menjadi struktur yang paling menentukan dalam proses perjalanan bangsa ini. Salah satu rekomendasi yang disebutkan dalam Kongres ke 18 yakni :

Dalam realitas kehidupan bidang politik, lembaga-lembaga perwakilan tersebut belum berfungsi optimal. Hal ini disebabkan karena terdapat kendala structural dan kultural. Secara struktur, sistem politik kita memberikan peluang yang besar terhadap dominannya peran eksekutif (pemerintah). Dan kultur politik yang berkembang kondusif terhadap berbagai hal di atas. Dominannya budaya paternialisme yang berkembang di masyarakat, mengakibatkan sistem politik yang patrimonial, sehingga hal ini semakin memperkuat posisi eksekutif (Kongres PB HMI, 1990).

Kritik HMI terhadap realitas politik Indonesia pada tahun 1990-an memperlihatkan semakin menguatnya hegemoni kekuasaan terhadap seluruh elemen bangsa, termasuk lembaga yudikatif dan legislatif. Maka untuk mengantisipasi kultur politik yang tidak dinamis, HMI menyarankan agar dilakukan penataan ulang terhadap sistem politik yang ada. Dalam rekomendasi pada Kongres ke 18 disebutkan: 
Untuk itu, maka perlu dilakukan penataan sistem politik yang memberikan peluang terhadap berperannya lembaga-lembaga perwakilan. Kemudian diikuti dengan peningkatan kualitas anggota perwakilan tersebut. Hal ini bisa dilakukan melalui perumusan peraturan perundang-undangan mengenai fungsi pengawasan DPR dan DPRD dan berfungsinya hak-hak DPR dan DPRD lainnya. Sehingga dengan demikian terdapat imbangan (balance) terhadap peran-peran pemerintah (Kongres PB HMI, 1990).

Peran yang dilakukan PB HMI menjelang reformasi 1998 dimulai dengan rekomendasi yang dihasilkan pada kongresnya ke-21, 20-26 Agustus 1997 di Yogyakarta. Rekomendasi tersebut berupa sikap politik HMI yang lebih cenderung melawan arus. Sikap politik ini lahir sebagai respon HMI terhadap kondisi sosial politik yang dinilai HMI mengalami perubahan, dimana masyarakat sudah jenuh dengan kondisi yang ada. Sikap politiknya tersebut antara lain; a) Perlunya dirumuskan kembali konsep ideologi Pancasila dalam implementasinya di segala bidang kehidupan baik secara teoritis maupun praktis. b) Berkaitan dengan aktualisasi dan sosialisasi nilai-nilai Pancasila, maka interpretasinya terhadap Pancasila tidak dimonopoli oleh golongan atau kepentingan tertentu. c) Dalam rangka menegakkan strong and clean goverment, maka pemerintah harus konsekuen dengan berbagai peraturan perundangan yang terkait, dalam arti tidak segan-segan menjatuhkan sanksi kepada aparatnya yang melakukan pelanggaran dan penyimpangan dalam tugasnya. d) Perlu dibuat Tap MPR tentang pembatasan masa jabatan presiden. e) Perlunya Komnas HAM dimasukkan dalam komisi khusus di DPR. f) Perlunya dibentuk lembaga independen yang bertugas mengawasi terjadinya korupsi dan kolusi di pemerintah. g) mendesak pemerintah untuk mengeluarkan Keppres tentang pembangunan Kawasan Timur Indonesia (KTI). h) Pemerintah dan DPR harus mereformasi 5 paket UU Politik. i) Revitalisasi dan reformasi Dwi Fungsi ABRI (Tap Kongres PB HMI ke-21, 1997).

Peran intelektual yang dilakukan PB HMI merupakan realitas sosial yang memiliki makna demokratis. Demokrasi yang dipahami sebagai paradigma pembangunan "Dari, Oleh Dan Untuk Rakyat" terus diperjuangkan oleh PB HMI dengan melakukan kegiatan dan program kerja yang dilandasai dengan nilai-nilai dasar perjuangan. Demokrasi kemerdekaan setiap individu menjadi keharusan utama, karena tidak ada sesuatu yang lebih berharga daripada kemerdekaan itu. Maka dalam sistem demokrasi, hak menyatakan pendapat dan bersuara harus dijamin oleh negara. Karena dalam masyarakat itulah kemerdekaan asasi 
diwujudkan. Meski dalam kemerdekaan pribadi itu maka timbul perbedaan-perbedaan antara satu pribadi dengan lainnya.

Sejalan dengan prinsip kemerdekaan dan kemanusiaan, dalam kehidupan yang teratur tiap-tiap orang harus diberi kesempatan untuk memilih dari beberapa kemungkinan dan untuk berpindah dari satu lingkungan ke lingkungan yang lain. Peningkatan kemanusiaan tidak dapat terjadi tanpa memberikan setiap orang keleluasaan untuk mengembangkan kecapakan melalui aktifitas dan kerja yang sesuai dengan kecenderungan dan bakatnya. Aktivitas kolektif yang dilakukan ternyata membawa hasil dengan menumbangkan rezim Orde Baru yang dikenal dengan Reformasi 1998. Konsolidasi kader terus dibangun secara kelembagaan untuk melegitimasi bahwa reformasi adalah sebuah keharusan (proses objektivikasi).

Upaya HMI dalam membangun demokrasi tidak hanya terhenti pada penurunan rezim orde baru, tapi memasukkan ide-ide demokasi yang selalu diskusikan oleh pengurus PB HMI dan kelompok Cipayung di Kantor PB HMI. Dengan keberadaan Anas Urbaningrum sebagai Tim revisi UU Politik merupakan upaya untuk mensosialisasikan ide dan gagasan tentang demokrasi (proses internalisasi). Diskusi tentang demokrasi, masalah kebangsaan dan pembangunan terus dilakukan, baik itu kantor PB HMI atau ditempat-tempat lainya (Ramdhansyah, 2014).

Pada Sidang Istimewa MPR 1998 memutuskan diadakan pemilu 1999, secara tidak langsung PB HMI mendukung pelaksanaan tersebut. Bahkan mengajak kepada seluruh elemen bangsa untuk menjadikan pemilu 1999 jujur, adil dan demokratis. Meski ada upaya perlawanan yang dilakukan oleh kelompok GAOB (Gerakan Anti Orde Baru) yang menganggap bahwa pemilu 1999 bukan salah satu agenda reformasi. Namun, bagi PB HMI dalam membangun demokasi harus dihindari bentuk anarkisme dalam menyikapi berbagai persoalan bangsa dan negara, karena mengutamakan moralitas politik. Untuk itu, mengembalikan gerakan mahasiswa kepada gerakan moral intelektual merupakan keharusan supaya tidak terjebak pada permainan kepentingan dan tujuan-tujuan politik yang tidak bermoral.

\section{HMI dalam Dinamika Demokrasi di Indonesia Pendukung Ideologi Negara (Pancasila)}

Sebagai negara yang menganut paham kebangsaan (Nation State), Indonesia menjadi negara yang tidak didasarkan pada ideologi keagamaan tertentu (negara teokrasi). Hampir semua agama (Islam, Katolik, Kristen, Hindu, Budha dan Konghucu) dapat berkembang dan berdampingan di Indonesia. Meskipun Indonesia dihuni hampir 87 
persen umat Islam, tapi nuansa toleransinya sangat terasa bahkan relatif harmonis. Tampak semenjak perumusan konstitusi negara di masa pergolakan kemerdekaan 1945, sikap pemimpin muslim merelakan Republik Indonesia berdiri tanpa mencantumkan secara formal Islam sebagai dasar Negara, namun menerima Pancasila.

Meski pada saat penyusunan konstitusi negara dan menjelang harihari kemerdekaan telah memperlihatkan adanya bibit-bibit ketegangan hubungan politik antara Islam dan Negara. Titik tekan penerimaan Pancasila bagi wakil-wakil Islam yakni pada sila pertama, tentang Ketuhanan. Wakil-wakil Islam pada saat sidang BPUPKI menerima sila ketuhanan yang berubah menjadi sila Ketuhanan Yang Maha Esa. Namun, dalam Majelis Konstituante, Pancasila yang sudah mengalami modifikasi ini dipertanyakan kembali oleh wakil-wakil Islam, karena masih belum merasa puas dengan perumusannya.

Ketidakpuasan tersebut dikarenakan Pancasila akan dikategorikan sebagai konsep murni, netral atau sekuler. Tekanan pendukung dasar Islam terhadap pembela Pancasila dilakukan karena kelompok tersebut tidak mampu menjelaskan bahwa Pancasila bukan sekuler, yang sangat ditentang oleh kelompok Islam. Seperti yang diungkapkan Soekarno, bahwa prinsip ketuhanan tidak mempunyai kaitan organik dengan doktrin sentral agama yang manapun. Konsep Ketuhanan dalam konsep Soekarno bersifat sosiologis sedangkan konsep Ketuhanan Soekarno sepenuhnya relatif; ia dapat diperas menjadi konsep gotong royong (Maarif, 2006: 146).

Meski pada akhirnya penerimaan Pancasila sebagai dasar negara telah berhasil mendamaikan polemik, namun ketegangan Islam dan negara tidak bisa dihilangkan begitu saja. Pemerintahan baik orde lama dan orde baru, menempatkan Islam politik sebagai pesaing kekuasaan yang mengancam basis kebangsaan. Islam politk dengan ambisinya untuk menjadikan Islam sebagai dasar negara dianggap sebagai bahaya yang mengancam persatuan. Persepsi semacam itu membuat negara berusaha menghalangi dan melakukan domestifikasi terhadap gerakan politik Islam sehingga meningkatkan ketegangan terus menerus.

Dinamika tersebut telah membawa perkembangan hubungan agama dan politik di Indonesia. Salah satu momentum politik yang dipengaruhi oleh gerakan Islam adalah penetapan Pancasila sebagai satu-satunya asas bagi semua organisasi, yang kemudian dikenal dengan asas tunggal, pada tahun 1980-an. Semula isu asas tunggal Pancasila menjadi masalah organisasi-organisasi politik, terutama partai-partai yang berasaskan Islam. 
Strategi PB HMI untuk menerima Pancasila sebagai asas semakin mendekatkan HMI kepada struktur masyarakat yang kuat yakni negara. Relasi dengan negara dibangun dengan menjaga dan melakukan komunikasi dengan legislatif dan eksekutif. Hingga Pengurus Besar HMI Periode 1997-1999, HMI masih menggunakan asas Pancasila. Pada Kongres ke 22 di Jambi bulan Desember 1999, memutuskan bahwa HMI kembali ke asas Islam dan berarti HMI kembali dari nilai identitas kader kepada Nilai Dasar Perjuangan.

\section{Mendorong Sistem Politik yang Pro-Demokrasi}

Dinamika sosial politik dalam masyarakat Indonesia pasca orde baru menunjukkan perubahan yang signifikan. Rupanya transformasi sosial politik tersebut telah memberikan ruang bagi civil society (masyarakat madani) untuk kembali bersuara kritis selama \pm 32 tahun lamanya mereka terkungkung dalam dominasi negara yang sangat sentralistik. Tidak ada secercah ruang pun untuk mengekspresikan gagasan-gagasan kritis dan brillian untuk membangun bangsa Indonesia ini, jika hal itu membahayakan eksistensi status quo.

Tumbangnya rezim otoriter Suharto, ibarat saluran air yang sudah lama tersumbat dan akhirnya ambrol karena tekanan air yang sangat kuat. Hak-hak politik dan kebebasan sipil dapat dinikmati, diskusi dan aktivitas lainnya dapat dilakukan tanpa ada rasa takut. Situasi tersebut hampir dirasakan oleh seluruh elemen masyarakat di Indonesia. Jika menggunakan parameter pemenuhan hak-hak politik dan kebebasan sipil seperti yang sering dipakai oleh lembaga Freedom House (Amerika Serikat), Indonesia termasuk kategori Negara Demokrasi. Keberhasilan pemilu-pemilu relatif bebas dan demokratis sejak 1999 makin mengukuhkan posisi Indonesia sebagai negara demokrasi terbesar ketiga di dunia sesudah India dan Amerika Serikat (Haris, 2014: X).

Reformasi 1998 berkaitan erat dengan proses demokratisasi dan beberapa perubahan-perubahan mendasar seperti perubahan UU dan amandemen UUD 1945. Selain merubah sistem pemerintahan yang lebih demokratis dan menyingkirkan budaya politik feodal serta menandai berakhirnya orde baru (setidaknya dari pemerintahan) dan hadirnya pemerintahan baru dengan kebijakan baru yang berbeda dari sebelumnya. Untuk membangun demokrasi yang sehat, Cak Nur menyampaikan pandangannya yang mungkin bisa meluruskan pelaksanaan demokrasi di Indonesia. Sejatinya demokrasi adalah sistem politik yang paling tepat dan mampu mengantarkan negara mencapai kehidupan yang sejahtera, negara yang adil dan makmur (Solichin, 2011: 370). 
HMI sebagai organisasi perjuangan dengan jumlah kader yang tersebar di seluruh Indonesia telah melakukan berbagai macam upaya strategis sebagai upaya memberikan kontribusi kepada bangsa dan negara. Organisasi yang telah melahirkan alumni yang tersebar di berbagai sektor pemerintahan ini telah turut berperan dalam merespon setiap kebijakan yang diambil organisasi. Peran Alumni HMI di legislatif, eksekutif dan yudikatif banyak membantu rekomendasi-rekomendasi HMI, bahkan hal itu tidak banyak diketahui bahwa PB HMI telah berusaha membawa ide dan gagasannya lewat alumni (Ramdhansyah, 2014).

Sebagai organisasi yang memiliki visi intelektual, tentu harus berpihak pada kebenaran dan keadilan. Kondisi ekonomi negara yang melemah dan nilai tukar rupiah terhadap dollar sangat rendah, mendorong PB HMI Periode 1997-1999 untuk bersikap. Peran PB HMI dalam kehidupan berbangsa dan bernegara menjadi terasa di masyarakat. Keterlibatan orang-orang HMI dalam pemerintahan yang menjadi pekerja langsung mempercepat proses penyampaian ide dan gagasan demokrasi. Seperti yang diungkapkan Gramsci, tugas intelektual organik adalah melahirkan aspirasi-aspirasi rakyat dan mewujudkan potensi yang secara inheren telah ada di dalam kelompok sosialnya. Hubungan erat antara kaum intelektual organik dengan kelas mereka merupakan sebuah proses yang dialektis; mereka melahirkan bentuk dari pengalaman kelas dan pada saat bersamaan menanamkan kesadaran pada rakyat. Terlibatnya Anas Urbaningrum dalam Tim Revisi UU Politik yang merupakan tuntutan reformasi dapat mendorong sistem politik Indonesia lebih demokratis. Ketelerbitannya langsung dalam proses dialektis tersebut, telah mendorong upaya demokratisasi dalam kehidupan berbangsa dan bernegara, demi terwujudnya masyarakat yang adil dan makmur.

\section{Pembangunan Civil Society}

Bagi bangsa Indonesia, Mei 1998 merupakan hari bersejarah yakni sejarah baru lahirnya politik mahasiswa. Turunnya Soeharto menjadi bangunan sejarah tersendiri bagi mahasiswa Indonesia. Mahasiswa pada penghujung akhir dasawarsa ini telah menorehkan tinta emas menghantarkan negeri ini memasuki era baru, era reformasi setelah sukses memaksakan pergantian orde baru yang korup (Urbaningrum, 1998: 34).

Civil society dan demokrasi saling bergantung sama lain, jika civil society kuat maka demokrasi akan tumbuh dan berkembang dengan baik. Begitu juga sebaliknya, ketika demokrasi dapat tumbuh dan berkembang 
dengan baik, civil soceity pun akan mengikutinya. Artinya bahwa civil society merupakan rumah tempat bersemayamnya demokrasi.

Pasca reformasi 1998, kebebasan politik telah memberi celah munculnya kekuatan-kekuatan politik baru yang selama orde baru tidak mungkin terjadi. Fungsi partai politik di era orde baru telah berubah menjadi multipartai pada pemilu 1999. Kekuatan organisasi masyarakat lainnya seperti LSM ataupun organisasi sejenis juga meningkat jumlahnya. Sistem demokrasi yang tumbuh dengan baik, akan tumbuh organisasi-organisasi yang dapat menopang pembangunan civil society.

Perubaan kelembagaan politik setelah reformasi mengalami perubahan, menguatnya lembaga-lembaga politik (eksekutif, legislatif dan yudikatif) dalam peran-perannya juga mekanisme prosedural seperti pemilihan umum yang lebih transparan dan adil bagi semua pihak. Aspek desentralisasi juga menjadi salah satu perubahan penting dalam tatanan kehidupan sosial politik di Indonesia karena kekuatan dan pergeseran politik di tingkat lokal pun menjadi lebih dinamis. Perubahan kelembagaan dan prosedur di dalam tatanan politik telah menjadi salah satu aspek penting yang terjadi dalam masa demokratisasi di Indonesia. Perubahan tersebut juga membawa dinamika yang menarik untuk diperhatikan lebih dalam, semisal yang terjadi di civil society dan juga partai politik. Kedua elemen ini dianggap oleh kalangan ilmuwan politik sebagai kekuatan yang mendorong dan mengarahkan jalannya demokratisasi di sebuah Negara.

Tumbuh dan kembangnya civil society setelah Orde Baru runtuh menimbulkan sebuah harapan baru yakni munculnya sebuah kekuatan yang penting dalam mendorong gerakan pembaharuan politik di Indonesia. Pada saat yang sama, Civil Society diuntungkan oleh struktur politik yang lebih terbuka karena memberikan kesempatan yang lebih luas dibandingkan pada masa orde baru. Akibatnya, politik seperti negosiasi dan lobi dengan penguasa politik yang dulu dianggap sebagai sesuatu hal yang dihindari oleh para aktornya, menjadi faktor penting yang harus dipertimbangkan kembali.

Kehadiran civil society yang dijamin kebebasannya juga menopang keberlangsungan partai politik, terutama untuk menghasilkan kebijakankebijakan yang berpihak kepada masyarakat. Tugas civil society adalah menghasilkan gagasan-gagasan yang konstruktif dalam pembangunan dan juga memonitor aparat negara serta kelompok-kelompok ekonomi. Sementara itu, tugas partai politik adalah menghasilkan dan membentuk konstitusi dan aturan-aturan perundang- undangan, mengontrol aparat birokrasi dan juga menghasilkan produk- produk kerangka kebijakan bagi semua pihak, termasuk kelompok ekonomi. 
Jika mengacu pada yang terjadi sekarang dimana di era reformasi ini harus ada kontrol dan pengawasan dari lembaga di luar lembaga negara, maka peran civil society inilah yang perlu diharapkan. Saat ini kita bisa melihat begitu banyaknya LSM dan ormas yang dulu ketika era orde baru tak pernah tampak perannya. Kita bisa melihat di media cetak dan elektronik bagaimana civil society mengontrol jalannya pemerintahan pusat maupun daerah.

Sebagai salah satu intelektual HMI di zamannya, M. Alfan Alfian berupaya menelusuri jejak reformasi di Indonesia yang memang tak dapat dilepaskan dari peristiwa Mei 1998. Dari peristiwa Mei dan peristiwa-peristiwa yang kemudian menyertainya, sesungguhnya banyak pelajaran yang dapat diambil. Penguatan civil society pun terjadi, namun dalam konstelasi politik secara makro meski mengalami anti klimaks. Kegagalan itu karena menguatnya power negara dan pasar, bukan pada masyarakat. Hal ini kerana gerakan mahasiswa dan kalangan muda mengalami kelesuan.

Menurut Alfan Alfian (2005) ada beberapa faktor yang menyebabkan, yakni Pertama, perubahan membutuhkan pengorbanan. Para mahasiswa yang gugur dalam peristiwa Mei, juga martir lain yang meninggal dalam kerusahan 13-14 Mei, tentu bukan tanpa makna. Mereka bukan sekedar victim, tetapi sudah menjadi bagian pemicu perubahan sejarah. Untuk perubahan disadari atau tidak, diniatkan atau kebetulan, mereka telah dikorbankan oleh pergolakan zaman. Kedua, reformasi ternyata lebih merupakan sebuah proses ketimbang hasil. Pergantian rezim kekuasaan, bukan berarti akhir dari tujuan gerakan reformasi. Justru setelah rezim berganti, ragam permasalahan menyeruak. Kondisi ini tidak berlangsung membaik. Banyak yang mesti dibenahi dalam setiap rezim yang bergantiganti. Reformasi adalah sebuah proses yang penuh tantangan di tengah kecenderungan demokrasi politik dan lingkungan ekonomi yang semakin liberal. Ketiga, penguatan civil society dalam konstelasi politik secara makro, mengalami kondisi pasca klimaks. Pasca-orde baru yang terjadi bukan penguatan civil society melainkan kekuatan-kekuatan politik diluar itu; utamanya negara (state) dan pasar (market). Gerakan mahasiswa dan kalangan muda mengalami kelesuan kembali, mereka seolah kehilangan momentum. Fenomena gagal konsolidasi terus terjadi pasca orde baru. Faksionalisme antar kekuatan kalangan mahasiswa dan pemuda (ditambah LSM) kelihatan makin meninggi di samping lambat laun kalah populer dengan kekuatan partai politik dan tidak ada apaapanya dibanding kekuatan pasar. 


\section{KESIMPULAN}

HMI merespon demokrasi tidak dengan mempertentangkan antara Islam dengan demokrasi. Negara Indonesia adalah negara dengan pemeluk agama Islam sebagai mayoritas dengan Pancasila sebagai dasar negara atau nasionalismenya yang sangat tinggi. HMI sebagai organisasi keagamaan yang berbasis Islam mampu menerima demokrasi sebagai ajaran Islam. Penelitian ini menjadi antitesis dari kelompok-kelompok yang menolak demokrasi. HMI menerima bahkan mendorong demokrasi demi untuk kepentingan nasional. Kontribusi pemikiran dan kepemimpinan melalui keterlibatan elit-elitnya di dalam membangun demokrasi dan pergumulan penegakan demokrasi di Indonesia. Sebagai kelompok intelektual yang memiliki kesadaran kolektif, aktivisme mahasiswa Islam agar memperkuat tradisi dalam menghasilkan ide dan gagasan sebagai bentuk tanggung jawab moral.

\section{DAFTAR PUSTAKA}

Alfian, A. (2013). HMI (Himpunan Mahasiswa Islam) 1963-1966 Menegakkan Pancasila di Tengah Prahara, Jakarta: Kompas.

Ali, A. S. (2012). Ideologi Gerakan Pasca-Reformasi, Jakarta: LP3ES.

Culla, A. S. (1999). Masyarakat Madani, Pemikiran, Teori dan Relevansinya dengan Cita-cita Reformasi, Jakarta: Raja Grafindo.

Djamal, M. (2015). Paradigma Penelitian Kualitatif . Yogyakarta: Mitra Pustaka.

Fakih, M. (2011). Jalan Lain: Manifesto Intelektual Organik, Yogyakarta: Pustaka Pelajar.

Gellner, E.(1995). Membangun Masyarakat Sipil: Prasyarat Menuju Kebebasan, Bandung: Mizan.

Giddens, A. (2002). Jalan Ketiga Pembaharuan Demokrasi Sosial, Terjemahan oleh Ketut Arya Mahardika dari The Third Way The Renewal of Social Democracy, Jakarta: Gramedia.

Gramsci, A. (2013). Prison Notebooks: Catatan-Catatan dari Penjara. Yogyakarta: Pustaka Pelajar.

Hadiz, V. R. (2005). Dinamika Kekuasaan Ekonomi Politik Indonesia PascaSoeharto, Jakarta: LP3ES.

Hakim, M. (2018). The Role of HMI in Socio-Political Change (A Case Study of Indonesia Under Soeharto Power, 1978-1998). 
International Journal of Scientific and Research Publications, Volume 8: No. 5, 2018: 374 - 386.

Haris, S. (2014). Masalah-Masalah Demokrasi dan Kebangsaan Era Reformasi, Jakarta: Yayasan Pustaka Obor Indonesia.

Hidayat, W., Soemanto, R. B. \& Supriyadi. (2020). Discourse of Gotong Royong Indonesian Democratic Party of Struggle in Kulon Progo, Special Region of Yogyakarta. Journal of Social and Political Sciences. Vol.3, No.1, 2020: 119-128.

Hutington, S. P. (1997). Gelombang Demokratisasi Ketiga, Terjemahan oleh Asril Marjohan dari The Third Wave Democratization in The Late Twentieth Century, Jakarta: Grafiti.

Koentjaraningrat. (1982). Metode-Metode Penelitian Masyarakat, Bandung: CV Transito.

Latif, Y. (2007). Intelegensia Muslim dan Kuasa: Genealogi Intelegensia Muslim Indonesia Abad ke-20, Bandung: Mizan.

Maarif, A. S. (2006). Islam dan Pancasila Sebagai Dasar Negara, Jakarta: LP3ES.

Maleong, L. J. (2000). Metodologi Penelitian Kualitatif, Bandung: Remaja Rosdakarya.

Mutahir, A. (2001). Intelektual Kolektif Pierre Bourdieu: Sebuah Gerakan untuk Melawan Domonisai. Yogyakarta: Kreasi Wacana.

Nawawi, H. (2005). Metode Penelitian Bidang Sosial, Yogyakarta: Gadjah Mada University Press.

Pusat Bahasa Depdiknas. (2001). Kamus Besar Bahasa Indonesia, Jakarta: Balai Pustaka.

Rakhmat, J. (1998). Islam Alternatif: Ceramah-Ceramah di Kampus, Bandung: Mizan.

Saleh, H. M. (1996). HMI dan Rekayasa Asas Tunggal Pancasila. Yogyakarta: Kelompok Lingkar Studi dan Pustaka Pelajar.

Satria, H.W. (2011). Lafran Pane: Jejak Hayat dan Pemikirannya. Jakarta: Penerbit Lingkar.

Seohadha, M. (2008). Metodologi Penelitian Sosiologi Agama. Yogyakarta: Bidang Akademik UIN Sunan Kalijaga.

Sitompul, A.S (ed). (2008). HMI Mengayuh Diantara Cita dan Kritik, Jakarta: CV Misaka Galiza. 
Wahyu Hidayat, Taufikurrahman

Sitompul, A.S. (2008). Menyatu dengan Umat, Menyatu dengan Bangsa: Pemikiran Keislaman-Keindonesiaan HMI (1947-1997), Jakarta: CV. Misaka Galiza.

Solichin. (2011). Wasiat Sang Begawan, Pesan-Pesan Nurcholis Majid, Jakarta: Sinergi Persadatama Foundation.

Supriyadi, E. (2003). Sosialisme Islam, Yogyakarta: Pustaka Pelajar.

Syari'ati, A. (1994). Ideologi Kaum Intelektual, Suatu Wawasan Islam, terj. Syafiq Bashri dan Haidar Baqir, Bandung: Mizan.

Tanja, V. (1982). HMI Sejarah dan Kedudukannya di Tengah-Tengah GerakanGerakan Muslim Pembaharu di Indonesia, Jakarta: Sinar Harapan.

Urbaningrum, A. (2014). Janji Kebangsaan Kita. Jakarta: Penerbit Sierr.

Zakaria, R. dkk (ed.). (2012). Membingkai Pengkaderan Intelektual Setengah Abad HMI Cabang Ciputat, Ciputat: UIN Jakarta Press.

Zamhari, M. H. (2004). Agama dan Negara, Analisis Kritis Pemikiran Politik Nurcholis Majid. Jakarta: Raja Grafindo. 